\title{
ANALISIS PUTUSAN PENGADILAN AGAMA MALANG TENTANG HAK TANGGUNGAN PADA SENGKETA EKONOMI SYARIAH (Studi Kasus Putusan Pengadilan Agama Malang nomor: 0689/Pdt.G/2017/PA.Mlg)
}

\author{
Arip Imawan \\ Abd Hadi \\ Universitas Muhammadiyah Surabaya \\ Universitas Islam Negeri Surabaya \\ Email: aripimawan@gmail.com
}

\begin{abstract}
The Malang Religious Court has the authority to decide cases on Islamic economic disputes. Decision numbered: 0689 / Pdt.G / 2017 / PA.Mlg is a ruling stating that they reject the plaintiff's claim regarding the cancellation of the mortgage. The formulation of the problem in this study was how the litigation procedure in the Sharia Economic Dispute Settlement of the Malang Religious Court and the legal basis for judges' consideration in deciding case number 0689 / Pdt.G / 2017 / PA.Mlg. This study used qualitative methods with primary data source for decision number 0689 / Pdt.G / 2017 / PA.Mlg and secondary data in the form of laws and regulations, DSN-MUI fatwa, documentation, and interview with judges of the Malang Religious Court. Conclusion Thesis, legal considerations used by the Panel of Judges in Decision Number: 0689 / Pdt.G / 2017 / PA.Mlg wereappropriate. These legal considerations used Law number 3 of 2006 and Law number 50 of 2009 concerning religious courts, Law number 4 of 1996 concerning mortgage rights and objects related to land, Law number 21 of 2008 concerning Islamic banking, DSN fatwa MUI number 11 / DSN-MUI / IV / 2000 concerning Kafalah and Perma number 2 of 2008 concerning Sharia Economic Law Compilation. However, in using consideration Permenkeu 106 / PMK.06 / 2013 was not appropriate because the Permenkeu had been revoked and was not valid because there was a Permenkeu 27 / PMK.06/2016.
\end{abstract}

Key Words : Sharia Economic Disputes, Mortgage Rights, Religious Courts

\section{PENDAHULUAN}

Peraturan hukum tentang Hak Tanggungan merupakan perangkat hukum yang bisa digunakan bila terjadi perjanjian atau kesepakatan pinjam meminjam antara Peminjam (Debitur) atau Nasabah dengan Pemberi Pinjaman (Kreditur) atau Bank. Guna mengetahui kemauan dan kemampuan nasabah dalam mengembalikan pinjaman agar tepat waktu ketika mengajukan permohonan kredit atau pembiayaan, biasanya bank akan mengkaji lima (5) hal yang meliputi Character (Kepribadian), Capacity (Kemampuan), Capital (Modal), Collateral (Agunan) dan Condition of Economy (Kondisi Ekonomi). Dari lima (5) hal tersebut, salah satu bagian yang terpenting adalah Collateral, yaitu sebuah barang yang diserahkan Debitur kepada Kreditor (Bank) sebagai jaminan 
terhadap pembayaran kembali atas kredit / pembiayaan yang diterimanya. ${ }^{1}$

Pasca pemberian kredit / pembiayaan, bank akan memberikan penilaian terhadap nasabah / Debiturnya terkait pembayaran angsuran yang diterimanya, bank akan memberi nilai baik dan lancar jika nasabah / Debiturnya dalam pembayaran angsuran bagus hingga tepat pelunasannya tepat waktu.

Namun ketika nasabah / Debiturnya tidak tepat waktu dalam pembayaran angsurannya atau bahkan cenderung telat hingga melewati jatuh tempo, maka Bank akan menilai bahwa nasabahnya / Debiturnya mengalami kredit macet, jika hal itu terjadi maka bank akan melakukan berbagai cara agar kreditnya tidak macet diantaranya bank memberikan somasi hingga menempuh jalur hukum, sebagaimana Pasal 6 dan Pasal 20 UU Nomor. 4 tahun 1996 tentang Hak Tanggungan, bank akan melakukan proses lelang terhadap jaminan Debitur.

Kasus kredit macet yang berujung pada sengketa perbankan banyak menghiasi berita di media cetak dan elektronik yang berujung ke pengadilan. Begitupula yang terjadi di Pengadilan Agama Malang, Pengadilan Agama kelas 1 A ini pada tanggal 7 April 2017 menerima permohonan gugatan sengketa Ekonomi Syariah yang teregister nomor 0689/Pdt.G/2017/PA.Mlg. Gugatan dilayangkan oleh Kantor Hukum Anggara \& Associates sebagai penerima kuasa dari penggugat atas nama Tukiran bin Sanapun dan Sunarti binti Sekak. Dalam gugatannya yang tertuang dalam provisinya agar majelis hakim menangguhkan pelaksanaan lelang atas nama nasabah Dhenny Mardau Eka Cahya, SE, sedangkan dalam konpensinya penggugat memohon pada

1 Adrian Sutedi, Hukum Hak Tanggungan, (Jakarta: Sinar Grafika, 2012), 13 hakim agar menyatakan bahwa Surat Kuasa Membebankan Hak Tanggungan (SKMHT) nomor 275 tanggal 27 Oktober 2017, dan Akta Pemberian Hak Tanggungan (APHT) nomor 241/2015 tanggal 17 Nopember 2015 serta Sertipikat Hak Tanggungan (SHT) nomor 5555/2015 dinyatakan tidak sah sehingga tidak mengikat menurut hukum. Para Penggugat beralasan bahwa Surat Kuasa Membebankan Hak Tanggungan, Akta Pemberian Hak Tanggungan dan Sertipikat Hak Tanggungan keberadaannya cacat hukum karena merujuk pada UU nomor 21 tahun 2008 tentang Perbankan Syariah tidak dikenal istilah Hak Tanggungan karena Hak Tanggungan berdasar pada hukum perdata barat / Burgerlik Wetboek (BW).

Hakim pemeriksa perkara 0689/Pdt.G/2017/PA.Mlg melakukan proses mediasi pada kedua belah pihak dengan harapan adanya perdamaian, namun proses mediasi tidak didapati kesepakatan dan dinyatakan tidak berhasil, perkara pun dilanjut ke persidangan. Dalam putusannya Majelis Hakim menolak gugatan penggugat secara keseluruhan.

Dari rangkaian latar belakang permasalahan tersebut, penulis tertarik untuk melakukan penelitian lebih mendalam tentang Putusan penolakan hakim pada gugatan pembatalan Surat Kuasa Membebankan Hak Tanggungan, Akta Pemberian Hak Tanggungan dan Sertipikat Hak Tanggungan tersebut. Selanjutnya penulis menuliskannya dalam bentuk jurnal dengan judul "Analisis Putusan Pengadilan Agama Malang Tentang Hak Tanggungan Pada Sengketa Ekonomi Syariah. (Studi Kasus Putusan Pengadilan Agama Malang Nomor 0689/Pdt.G/2017/PA.Mlg)"

Berdasarkan latar belakang tersebut, penulis melakukan pembatasan masalah 
dengan tujuan agar penulis dapat lebih fokus dalam melakukan analisanya sebagai berikut:

1. Proses penyelesaian Sengketa Ekonomi Syariah di Pengadilan Agama Malang.

2. Putusan Pengadilan Agama Malang nomor 0689/Pdt.G/2017/PA.Mlg.

Rumusan masalah yang menjadi objek penulisan adalah Bagaimana prosedur berperkara dalam Penyelesaian Sengketa Ekonomi Syariah Pengadilan Agama Malang? Dan Bagaimana dasar hukum yang dipakai sebagai pertimbangan Hakim dalam memutus perkara nomor 0689/Pdt.G/2017/PA.Mlg?

Sebagaimana dengan rumusan masalah diatas, maka tujuan penelitian ini untuk mengenal, memahami, mendalami, dan mengungkap persoalan yang terkait keabsahan Hak Tanggungan berdasarkan Putusan Pengadilan Agama Malang nomor 0689/Pdt.G/2017/PA.Mlg, sehingga penulis dapat mengetahui prosedur berperkara dalam Penyelesaian Sengketa Ekonomi Syariah di Pengadilan Agama Malang. Dan mengetahui dasar hukum apa yang dipakai pertimbangan majelis Hakim dalam memutus perkara nomor 0689/Pdt.G/2017/PA.Mlg.

\section{KERANGKA TEORI}

\section{Putusan Pengadilan Agama}

Dalam Kitab Undang - Undang Hukum Acara Pidana, pengertian putusan pengadilan adalah pernyataan hakim yang diucapkan dalam sidang pengadilan terbuka yang dapat berupa pemidanaan atau bebas atau lepas dari segala tuntutan hukum dalam hal serta menurut cara yang diatur dalam undang - undang ini. ${ }^{2}$

Berdasar pengertian diatas, dapat dikatakan bahwasanya putusan
Pengadilan Agama adalah putusan yang diucapkan atau dinyatakan oleh hakim dalam sidang pengadilan agama yang dapat berupa tuntutan atau lepas dari tuntutan hukum akibat adanya sengketa atau perselisihan kedua belah pihak yang berperkara sebagaimana yang diatur dalam peraturan perundang - undangan yang berlaku.

\section{Pertimbangan Hakim}

Dalam pasal 183 dan 184 KUHAP "Seorang hakim dalam hal menjatuhkan pidana kepada terdakwa tidak boleh menjatuhkan pidana tersebut kecuali apabila dengan sekurang - kurangnya dua alat bukti yang sah, sehingga hakim memperoleh keyakinan bahwa suatu tindak pidana benar - benar terjadi dan terdakwalah yang bersalah melakukannya. Alat bukti sah yang dimaksud adalah: (a). Keterangan Saksi; (b).Keterangan Ahli; (c). Surat; (d). Petunjuk; (e). Keterangan terdakwa atau hal yang secara umum sudah diketahui sehingga tidak perlu dibuktikan". ${ }^{3}$

Dengan demikian pengertian Pertimbangan Hakim adalah segala sesuatu yang menjadi dasar sebelum memutus suatu perkara tindak pidana maupun perdata dengan memperhatikan setiap hal yang penting dalam suatu persidangan berdasarkan alat bukti yang sah berupa keterangan saksi, keterangan ahli, bukti surat, maupun petunjuk lainnya agar hakim memperoleh keyakinan dalam memutus perkara yang ditanganinya.

\section{Hak Tanggungan}

Hak Tanggungan menurut pasal 1 ayat (1) Undang - Undang nomor 4 tahun 1996 Tentang Hak Tanggungan atas tanah beserta benda - benda yang berkaitan dengan tanah adalah hak jaminan yang 
dibebankan pada hak atas tanah sebagaimana dimaksud dalam Undang Undang Nomor 5 Tahun 1960 tentang Peraturan Dasar Pokok - Pokok Agraria, berikut atau tidak berikut benda - benda lain yang merupakan satu kesatuan dengan tanah itu, untuk pelunasan utang tertentu, yang memberikan kedudukan yang diutamakan kepada kreditor tertentu terhadap kreditor - kreditor lain. ${ }^{4}$

Objek Hak Tanggungan diatur dalam pasal 4 ayat (1) Undang - Undang nomor 4 tahun 1996 tentang Hak Tanggungan yang berbunyi "Hak atas tanah yang dapat dibebani Hak Tanggungan adalah: (1) Hak Milik; (2) Hak Guna Usaha; (3). Hak Guna Bangunan”.

Sedangkan subjek Hak Tanggungan, diatur dalam Pasal 8 Undang - Undang nomor 4 tahun 1996 tentang Hak Tanggungan yang berbunyi "Pemberi Hak Tanggungan adalah orang perseorangan atau badan hukum yang mempunyai kewenangan untuk melakukan perbuatan hukum terhadap obyek Hak Tanggungan yang bersangkutan".

Kewenangan untuk melakukan perbuatan hukum terhadap obyek Hak Tanggungan sebagaimana dimaksud pada ayat (1) harus ada pada pemberi Hak Tanggungan pada saat pendaftaran Hak Tanggungan dilakukan. Sedangkan Pasal 9 Undang - Undang nomor 4 tahun 1996 tentang Hak Tanggungan berbunyi "Pemegang Hak Tanggungan adalah orang perseorangan atau badan hukum yang berkedudukan sebagai pihak yang berpiutang".

Dari ketentuan pasal 8 dan 9 tersebut, penulis beranggapan bahwa dalam melakukan suatu perjanjian hak tanggungan harus ada dua belah pihak yang mengikatkan diri, yaitu: Pemberi Hak Tanggungan, yaitu orang atau pihak

${ }^{4}$ UU no 4 tahun 1996 Tentang Hak Tanggungan atas tanah beserta benda-benda yang berkaitan dengan tanah yang menjaminkan objek hak tanggungan (debitor); Pemegang Hak Tanggungan, yaitu orang atau pihak yang menerima Hak Tanggungan sebagai jaminan dari piutang yang diberikannya.

\section{Sengketa Ekonomi Syariah}

Pengertian Sengketa Ekonomi Syariah Sengketa adalah pertikaian, perselisihan, sesuatu yang menyebabkan perbedaan pendapat, sebuah konflik yang berkembang atau berubah menjadi sebuah sengketa apabila pihak yang merasa dirugikan telah menyatakan rasa tidak puas atau keprihatinannya baik secara tidak langsung kepada pihak yang dianggap sebagai penyebab kerugian atau kepada pihak lain. $^{5}$

Penyelesaian sengketa ekonomi syariah bisa ditempuh dengan dua cara, yaitu cara non litigasi dan cara litigasi.

Non Litigasi adalah cara sederhana dalam menyelesaian sengketa ekonomi syariah. Adapun prinsip yang dipegang dalam menyelesaikan sengketa ekonomi syariah non litigasi dengan cara perdamaian (sulhu) dan mediasi. Sedangkan Litigasi adalah penyelesaian sengketa ekonomi syariah melalui jalur pengadilan.

Proses bersengketa Ekonomi Syariah di Pengadilan Agama Malang dengan cara mengajukan gugatan secara tertulis atau lisan kepada Pengadilan Agama Malang (Pasal 118 HIR, 142 R.Bg). Gugatan diajukan kepada Pengadilan Agama Malang. Membayar biaya perkara (Pasal 121 ayat (4) HIR, 145 ayat (4) R.Bg. Jo. Pasal 89 UU No. 7 Tahun 1989 yang telah diubah dengan UU No. 3 Tahun 2006), bagi yang tidak mampu dapat berperkara secara cuma-cuma (prodeo) (Pasal 237 HIR, 273 R.Bg). Penggugat dan Tergugat atau kuasanya menghadiri sidang

\footnotetext{
${ }^{5}$ M Marwan \& Jimmy P, Kamus Hukum, (Surabaya: Reality Publisher, 2009), 560
} 
pemeriksaan berdasarkan panggilan pengadilan agama/ mahkamah syar'iyah (Pasal 121, 124, dan 125 HIR, 145 R.Bg). ${ }^{6}$

\section{METODE PENELITIAN}

Metode penelitian merupakan cara kerja yang digunakan untuk memahami suatu masalah dan cara memecahkan masalah dari sebuah penelitian itu sendiri dengan berdasarkan pada metode tertentu. Agar penelitian ini berjalan baik dan hasilnya dapat dipertanggungjawabkan secara ilmiah, maka diperlukan suatu metode penelitian yang sistematis. Adapun metode yang penulis gunakan sebagai berikut:

\section{A. Jenis Penelitian}

Jenis penelitian ini merupakan penelitian studi kasus yang menggunakan jenis penelitian kualitatif, yaitu sebuah penelitian yang lebih menekankan pada aspek pemahaman secara mendalam terhadap suatu masalah tertentu yang ditelitinya. ${ }^{7}$

Penelitian ini dilakukan dengan menelaah kasus yang berkaitan dengan putusan pengadilan yang berkekuatan hukum tetap. Hal pokok yang dikaji adalah pertimbangan hakim hingga sampai pada putusan akhir, sehingga dapat dijadikan argumentasi dalam memecahkan isu hukum yang sedang dihadapi.

\section{B. Sumber Data Penelitian}

Adapun sumber data yang digunakan oleh penulis dalam penelitian ini adalah data primer yaitu Direktori putusan perkara nomor 0689/Pdt.G/2017/PA.Mlg.

Selain data primer tersebut, penulis juga menggunakan sumber data sekunder

\footnotetext{
${ }^{6} \mathrm{https}: / / w w w . p a-m a l a n g k o t a . g o . i d / p a g e s /$ sejarah. (20 Agustus 2017)

${ }^{7}$ https://www.gurupendidikan.co.id/metode-penelitiankualitatif/ (14 Juni 2020)
}

untuk menguatkan data primer yang dapat dipergunakan untuk memperjelas konsep dalam penelitian tersebut. Data sekunder yang penulis peroleh dari hasil wawancara dengan Sekretaris Pengadilan Agama Malang dan Hakim yang memeriksa perkara nomor 0689/Pdt.G/2017/PA.Mlg, hal tersebut penting untuk mendapatkan data yang akurat dalam penelitian ini.

Data Sekunder lainnya berupa peraturan perundang - undangan dan fatwa DSN-MUI, tesis dan jurnal hasil penelitian terdahulu, buku - buku dan literatur literatur, artikel - artikel yang berkaitan dengan permasalahan yang sedang diteliti.

\section{Teknik Pengumpulan Data}

Teknik pengumpul data yang penulis lakukan yaitu studi dokumen atau bahan pustaka, pengamatan, dan wawancara.

\section{PEMBAHASAN}

\section{A. Gambaran Umum Pengadilan Agama Malang}

Pengadilan Agama Malang adalah Pengadilan Agama kelas 1 A yang beralamat di jalan R. Panji Suroso nomor 1 Kota Malang.

Berdasarkan Pasal 2 jo. Pasal 49 Undang-Undang Nomor 3 Tahun 2006 tentang Perubahan atas Undang-undang Nomor 7 Tahun 1989 Tentang Peradilan Agama, Tugas pokok Pengadilan Agama adalah memeriksa, memutus, dan menyelesaikan perkara tertentu antara orang - orang yang beragama Islam di bidang: Perkawinan, Waris, Wasiat, Hibah, Wakaf, Zakat, Infaq, Shadaqah; dan Ekonomi Syari'ah.

Sebagaimana amanat Undang Undang nomor 3 tahun 2006 yang mengamandemen Undang - Undang nomor 7 tahun 1989 tentang Peradilan Agama, ditambah dengan adanya Putusan Mahkamah Konstitusi nomor 93/PUU-X/2012 tentang Pengujian 
Terhadap Undang - Undang nomor 21 tahun 2008 tentang Perbankan Syariah yang menghapus dualisme lembaga peradilan dalam menyelesaikan sengketa ekonomi syariah, Pengadilan Agama Malang pun menyesuaikan diri dalam penerimaan perkara sengketa ekonomi syariah yang masuk ke Pengadilan Agama Malang.

\section{B. Penyajian Data}

1. Penyelesaian Sengketa Perdata di Pengadilan Agama Malang.

Penyelesaian sengketa ekonomi syariah di Pengadilan Agam Malang bisa dilakukan dengan cara mengajukan gugatan secara sederhana atau gugatan biasa.

1) Gugatan Sederhana berdasarkan Peraturan Mahkamah Agung Republik Indonesia Nomor 4 Tahun 2019 Tentang Tata Cara Penyelesaian Gugatan Sederhana adalah tata cara pemeriksaan di persidangan terhadap gugatan perdata dengan nilai gugatan materil paling banyak Rp. 500.000.000,00 (Lima ratus juta rupiah) yang diselesaikan dengan tata cara dan pembuktiannya sederhana. Gugatan sederhana diajukan terhadap perkara cidera janji dan/atau perbuatan melawan hukum dengan waktu penyelesaian gugatan sederhana paling lama 25 (dua puluh lima) hari sejak hari sidang pertama.

2) Gugatan Biasa. Dalam Gugatan Biasa prosedur yang harus dilakukan Penggugat sebagai berikut:

a) Mengajukan gugatan secara tertulis atau lisan kepada Pengadilan Agama / Mahkamah Syar'iyah berdasarkan kompetensi relatif, yaitu pengadilan tersebut berwenang menangani perkara yang yang dimaksud berdasar tempat tinggal tergugat atau domisili hukum yang ditunjuk dalam sebuah perjanjian. (Pasal 118 HIR, 142 R.Bg).

b) Membayar biaya perkara (Pasal 121 ayat (4) HIR, 145 ayat (4) R.Bg. Jo. Pasal 89 UU No. 7 Tahun 1989 yang telah diubah dengan UU No. 3 Tahun 2006), bagi yang tidak mampu dapat berperkara secara cuma-cuma (prodeo) (Pasal 237 HIR, 273 R.Bg.)

c) Penggugat dan Tergugat atau kuasanya menghadiri sidang pemeriksaan berdasarkan panggilan Pengadilan Agama / Mahkamah Syar'iyah (Pasal 121, 124, dan 125 HIR, 145 R.Bg).

\section{Deskripsi Perkara Nomor 0689/Pdt.G/2017/PA.Mlg}

Untuk membahas lebih dalam, penulis akan menguraikan deskripsi perkara nomor 0689/Pdt.G/2017/PA.Mlg pada Sengketa Ekonomi Syariah di Pengadilan Agama Malang sebagai berikut:

a. Kasus Posisi

Pada tanggal 7 April 2017 Pengadilan Agama Malang menerima permohonan gugatan Sengketa Ekonomi Syariah yang teregister nomor 0689/Pdt.G/2017/PA.Mlg. Dalam gugatannya yang tertuang dalam provisinya agar majelis hakim menangguhkan pelaksanaan lelang atas nama nasabah Dhenny Mardau Eka Cahya, SE, sedangkan dalam konpensinya para penggugat memohon pada majelis hakim untuk menyatakan bahwa Surat Kuasa Membebankan Hak Tanggungan nomor 275 tanggal 27 Oktober 2015, dan Akta Pemberian Hak Tanggungan nomor 241/2015 tanggal 17 Nopember 2015 serta Sertipikat Hak Tanggungan nomor 5555/2015 dinyatakan tidak sah sehingga 
tidak mengikat menurut hukum.

Hakim pemeriksa perkara 0689/Pdt.G/2017/PA.Mlg dalam

putusannya tertanggal 12 Desember 2017 bertepatan dengan 23 Rabiul Awal 1439 menyatakan menolak gugatan penggugat secara keseluruhan.

b. Para Pihak

1) Penggugat

a) Tukiran bin Sanapun yang beralamatkan di Jalan Raya Kapiworo 16 RT 3 RW 12 Desa Mangliawan Kecamatan Pakis Kabupaten Malang sebagai Penggugat I.

b) Sunarti binti Sekak yang beralamatkan di Jalan Raya Kapiworo 16 RT 3 RW 12 Desa Mangliawan Kecamatan Pakis Kabupaten Malang sebagai Penggugat II.

2) Tergugat

a) Kepala PT Bank BNI Syariah Kantor Cabnag Dinoyo yang beralamat di Jalan Tlogomas Kecamatan Lowokwaru Kota Malang sebagai Tergugat I.

b) Dhenny Mardanu Eka Cahya, SE bin Agung Sunyoto yang beralamat di Jalan Werkudoro nomor 12 RT 4 RW 3 Kelurahan Polehan Kecamatan Blimbing Kota Malang sebagai Tergugat II.

c) Yenni, SE binti Mulyadi yang beralamat di Jalan Werkudoro nomor 12 RT 4 RW 3 Kelurahan Polehan Kecamatan Blimbing Kota Malang sebagai Tergugat III.

3) Turut Tergugat.

a) Notaris \& PPAT Leslie Arnia Diajeng, $\mathrm{SH}, \mathrm{MKn}$ yang beralamat di Jalan Terusan Danau Kerinci Blok 1A nomor 1 Desa Mangliawang
Kecamatan Pakis Kabupaten Malang sebagai Turut Tergugat I.

b) Kepala Badan Pertanahan Nasional (BPN) Kabupaten Malang yang beralamat di Jalan Terusan Kawi nomor 10 Kelurahan Gading Kasri Kecamatan Klojen Kota Malang sebagai Turut Tergugat II.

c) Kepala Kantor Pelayanan Kekayaan Negara Dan Lelang (KPKNL) Malang yang beralamat di Jalan $S$ Supriyadi nomor 157 Kelurahan Bandungrejosari Kecamatan Sukun Kota Malang sebagi Turut Tergugat III.

c. Pokok Gugatan

Dalam gugatannya Penggugat memohon penangguhan pelaksanaan lelang atas nama nasabah Dhenny Mardanu Eka Cahya, SE atas sebuah rumah di Jalan Kapi Woro nomor 16 RT 3 RW 12 Desa Mangliawan Kecamatan Pakis Kabupaten Malang luas 198 M2 tertulis atas nama Tukiran Sertipikat Hak Tanggungan nomor 5555/2015. Sedangkan dalam pokok perkara Penggugat memohon agar Majelis Hakim menyatakan bahwa Surat Kuasa Membebankan Hak Tanggungan nomor 275 tanggal 27 Oktober 2015, Akta Pemberian Hak Tanggungan nomor 241/2015 tanggal 17 Nopember 2015 dan Sertipikat Hak Tanggungan nomor 5555/2015 adalah tidak sah sehingga tidak mengikat menurut hukum.

d. Duduk Perkara

1) Bahwa Tergugat II dan Tergugat III mengajukan pembiayaan Murabahah senilai Rp. 220.037.200 (Dua Ratus Dua Puluh Juta Tiga Puluh Tujuh Ribu Dua Ratus Rupiah) pada 
Tergugat I sesuai perjanjian Akad Pembiayaan Murabahah nomor 274 tanggal 27 Oktober 2015 dibuat dihadapan Turut Tergugat I.

2) Bahwa dari Akad pokok pembiayaan Murabahah tersebut timbul perjanjian tambahan (accecoir) berupa Surat Kuasa Membebankan Hak Tanggungan nomor 275 tanggal 27 Oktober 2015 dan Akta Pemberian Hak Tanggungan nomor 241/2015 tanggal 17 Nopember 2015 dibuat oleh dan dihadapan Turut Tergugat I, yang selanjutnya oleh Turut Tergugat I didaftarkan ke Turut Tergugat II, kemudian oleh Turut Tergugat II diterbitkanlah Sertipikat Hak Tanggungan nomor 5555/2015.

3) Bahwa menurut Undang - undang nomor 21 tahun 2008 tentang Perbankan Syariah pasal 2 menyatakan : "Perbankan Syariah dalam melakukan kegiatan usahanya berasaskan Prinsip Syariah, demokrasi ekonomi, dan prinsip kehati - hatian “, sehingga seharusnya akad jaminan sebagai perjanjian tambahan (assesoir) yang dibuat adalah Rahn atau dalam Kompilasi Hukum Ekonomi Syariah Islam ada juga istilah Kafalah, yaitu jaminan atau garansi yang diberikan oleh penjamin kepada pihak ketiga / atau pemberi pinjaman untuk memenuhi kewajiban pihak kedua / peminjam, bukan dengan Hak Tanggungan yang berdasarkan hukum perdata barat / Burgerlik Wetboek (BW).

4) Bahwa tanpa melalui musyawarah dan mufakat sesuai prinsip syariah, pada tanggal 14 Maret 2017 melalui surat nomor $\mathrm{KCM} / 863$ 0/152/03/2017 rumah jaminan pembiayaan Murabahah tersebut didaftarkan lelang oleh Tergugat I kepada Turut Tergugat III

5) Bahwa sesuai Fatwa Dewan Syariah Nasional nomor 47/DSNMUI/II/2005 tanggal 17 Pebruari 2005 / 08 Muharram $1425 \mathrm{H}$ tentang Penyelesaian Piutang Murabahah Bagi Nasabah Tidak Mampu Membayar bagian pertama ketentuan penyelesaian : LKS boleh melakukan penyelesaian (settlement) murabahah bagi nasabah yang tidak bisa menyelesaikan / melunasi pembiayaanya sesuai jumlah dan waktu yang telah disepakati dengan ketentuan : a. Objek Murabahah atau jaminan lainnya dijual oleh nasabah kepada atau melalui LKS dengan harga pasar yang disepakati”. Sehingga lelang atas jaminan Murabahah rumah milik para Penggugat yang akan dilakukan Turut Tergugat III adalah bertentangan / melanggar syariah Islam.

6) Bahwa demi kepastian hukum sangat beralasan jika para Penggugat minta putusan pendahuluan / provisional agar pelaksanaan lelang terhadap rumah jaminan Murabahah yaitu di Jalan Raya Kapi Woro 16 RT 3 RW 12 Desa Mangliawan Kecamatan Pakis Kabupaten Malang sesuai SHM nor 03987/Desa Mangliawan luas 198 M2 atas nama Tukiran dengan Sertipikat Hak Tanggungan nomor 5555/2015 ditangguhkan pelaksanaan lelangnya sampai putusan perkara ini memperoleh kekuatan hukum tetap (inkracht).

7) Bahwa karena Hak Tanggungan tidak dikenal dalam pembiayaan Murabahah dan jelas tidak sesuai dengan prinsip Syariah Islam, maka perjanjian tambahan (assesoir) guna 
terbitnya Hak Tanggungan tersebut, yaitu : Surat Kuasa Membebankan Hak Tanggungan nomor 275 tanggal 27 Oktober 2015, Akta Pemberian Hak Tanggungan nomor 241/2015 tanggal 17 Nopember 2015 dan Sertipikat Hak Tanggungan nomor $5555 / 2015$ adalah tidak sesuai dengan hukum Islam / Syariah, maka harus dinyatakan cacat hukum tidak sah sehingga harus dibatalkan dan tidak mempunyai kekuatan hukum mengikat.

8) Bahwa perkara ini merupakan kompetensi absolute Pengadilan Agama berdasarkan pasal 49 huruf (1) Undang - Undang nomor 3 tahun 2006 tetang Peradilan Agama, perkara ekonomi Syariah, termasuk Perbankan Syariah merupakan kewenangan absolute Peradilan Agama, dan pasal 55 ayat (1) yang menyatakan bahwa sengketa perbankan syariah diselesaikan di pengadilan dalam lingkungan peradilan Agama, serta dengan putusan MK nomor 93/PUU-X/2012 yang pada pokoknya menyatakan penjelasan pasal 55 ayat (2) Undang - Undang nomor 21 tahun 2008 tentang Perbankan Syariah tidak bertentangan dengan Undang Undang Dasar Republik Indonesia tahun 1945 dan tidak mempunyai kekuatan hukum mengikat.

9) Berdasarkan dasar / alasan diatas, maka para Penggugat memohon pada ketua Pengadilan Agama Malang berkenan memanggil, memeriksa, dan memutus sebagai berikut:

a) Dalam Provisionilnya:

Menangguhkan pelaksanaan lelang atas nama nasabah Dhenny Mardanu Eka Cahya, SE atas sebuah rumah di Jalan Kapi Woro
16 RT 3 RW 12 Desa Mangliawan Kecamatan Pakis Kabupaten Malang SHM nomor 03987/Desa Mangliawan, luas 198 M2 tertulis atas nama Tukiran Sertipikat Hak Tanggungan nomor 5555/2015.

b) Dalam Kompensi para Penggugat memohon agar Hakim :

i. Mengabukan gugatan Para Penggugat untuk seluruhnya

ii. Menyatakan Surat Kuasa Membebankan HakTanggungan nomor 275 tanggal 27 Oktober 2015 adalah tidak sah sehingga tidak mengikat menurut hukum

iii. Menyatakan Akta Pemberian Hak Tanggungan nomor 241/2015 tanggal 17 Nopember 2015 adalah tidak sah sehingga tidak mengikat menurut hukum

iv. Menyatakan Sertipikat Hak Tanggungan nomor 5555/2015 adalah tidak sah sehingga tidak mengikat menurut hukum

v. Memerintahkan Tergugat I untuk meroya / mengembalikan SHM nomor 03987/Desa Mangliawan pada keadaan semuala yaitu bersih dari Hak Tanggungan

vi. Menghukum para Turut Tergugat untuk tunduk dan patuh pada putusan ini

vii. Membebankan biaya perkara sesuai ketentuan hukum, atau yang Mulia Majelis Hakim berpendapat lain mohon putusan yang seadil - adilnya.

e. Putusan Hakim Perkara Nomor 0689/Pdt.G/2017/PA.Mlg

Dalam sidang putusan Hakim membacakan pertimbangannya sebagai berikut:

1) Dalam Provisi

a) Menimbang bahwa dalam 
$\begin{aligned} & \text { gugatannya para } \\ & \text { meminta } \\ & \text { pendahuluan }\end{aligned}$
$\begin{array}{r}\text { Penggugat } \\ \text { tindakan } \\ \text { Gugatan }\end{array}$

Provisionil oleh pengadilan untuk menanggughakn pelaksanaan lelang atas nama nasabah Dhenny Mardanu Eka Cahya, SE atas sebuah rumah di Jalan Raya Kapi Woro 16 RT 3 RW 12 Desa Mangliawan Kecamatan Pakis Kabupaten Malang, SHM nomor 03987/Desa Mangliawan luas $198 \quad$ M2 tertulis atas nama Tukiran Sertipikat Hak Tanggungan nomor 5555/2015.

b) Menimbang bahwa pelaksanaan lelang dalam perkara aquo baru sampai pada tahap pendaftaran dan belum sampai pada tindakan untuk ditetapkannya lelang dan / atau tahap pengumuman lelang sebagai bukti bahwa tindakan leleang benar - benar akan dilaksanakan oleh kantor Pelayanan Kekayaan Negara dan Lelang Malang.

c) Menimbang bahwa berdasarkan pasal 13 Peraturan Menteri Keuangan Republik Indonesia nomor 106/Pmk.06/2013 tentang Perubahan Atas Peraturan Lelang yang selengkapnya berbunyi: (1) Dalam hal terdapat gugatan terhadap objek leleng Hak Tanggungan dari pihak lain selain debitur / tereksekusi. Suami atau istri debitur / tereksekusi yang terkait kepemilikan, pelaksanaan lelang dilakukan berdasarkan title eksekutorial dari Sertipikat Hak
Tanggungan yang memerlukan fiat eksekusi. (2) Permohonan atas pelaksanaan lelang sebagaimana dimaksud ayat (1) dilakukan oleh pengadilan.

d) Menimbang berdasarkan alasan - alasan yang diuraikan diatas, maka gugatan provisional para Penggugat untuk menangguhkan pelaksanaan lelang atas perkara aquo dinilai oleh majelis Hakim sebagai permintaan yang belum waktunya / premature, yang dilator belakangi kekhawatiran yang berlebihan, oleh karena itu maka harus dinyatakan tidak dapat diterima.

2) Dalam Gugatan Pokok

a) Menimbang bahwa gugatan Penggugat pada pokoknya meminta kepada Pengadilan Agama Malang untuk membatalkan Akad Penjaminan hukum atas perjanjian yang dilakukan oleh para Penggugat sebagai Penjamin terhadap Tergugat I sebagai Penerima jaminan atas sejumlah hutang dari Tergugat II dan Tergugat III terhadap Tergugat I yang selanjutnya tertuang dalam : Surat Kuasa Membebankan Hak Tanggungan nomor 275 tanggal 27 Oktober 2015, Akta Pemberian Hak Tanggungan nomor 241/2015 tanggal 17 Nopember 2015, Sertipikat Hak Tanggungan nomor 5555/2015,

b) Menimbang bahwa dasar perjanjian atas pembebanan Hak Tanggungan adalah hukum BW dan / atau 
peraturan perundang undangan lain yang dianggap bertentangan / melanggar syariat Islam

c) Menimbang bahwa berdasarkan doktrin dalam teori usul fikih Islam antara lain menyatakan "pada asasnya semua jenis muamalat dan perjanjian / perikatan adalah saling ridho / rela dan tidak sah muamalat serta tidak sah pula suatu perjanjian / perikatan tanpa adanya kerelaan sejak awalnya. Kerelaan dalam muamalat dan perjanjian / perikatan itu hanya mungkin ada / harus sudah ada pada permulaan (proses)". Imam Ibnu Taimiyah berpendapat "bahwa asal dari semua yang terlihat dan berwujud di alam dunia dengan segala fariasi dan sifatnya adalah mubah (dibolehkan) dan halal bagi manusia sepanjangtidak dinyatakan oleh syariat tentang keharaman dan / atu kenajisannya untuk dimakan, dipakai dan diperjanjikannya, asas yang demikian itu sangat banyak manfaatnya sangatluas keberkahannya".

d) Menimbang berdasarkan kaedah - kaedah dalam hukum Islam tersebut, maka semua produk peraturan perundang undangan dan semua jenis perikatan sepanjang menurut sifat dan substansinya tidak bertentangan / diharamkan oleh syariat Islam berarti sah dan mengikat.

e) Menimbang berdasarkan uraian tersebut diatas maka dalil gugatan para Penggugat yang menyatakan bahwa pembebanan Hak Tanggungan dalam perkara aquo dengan menggunakan peraturan perundang - undangan dalam KUHPerdata / BW dan Undang - Undang nomor 4 tahun 1996 sebagai tindakan yang bertentangan dengan syariat Islam adalah suatu kekeliruan dalam memahami substansi Hukum Islam.

f) Menimbang bahwa pembebannan Hak Tanggungan dalam khazanah hukum Islam disebut kafalah merupakan praktek muamalah yang dibolehkan dalam Syariat islam, antara lain sebagaimana dikemukan Dr Wahba Zuhaili yang menyatakan "Kafalah (pertanggungan) secara general adalah suatu yang masyru' (diperbolehkan oleh syariat Islam) berdasarkan Al Qur'an, As Sunnah dan Ijma' (kesepakatan para ulama). Adapun dalil dari Al Qur'an terdapat dalam Surat Yusuf ayat 72 bunyinya "penyeru penyerru itu berkata: kami kehilangan piala raja, dan siapa yang dapat mengembalikannya akan memperoleh bahan makanan (seberat) beban unta, dan aku menjamin terhadapnya" adapun dasar dari As Sunnah / Al Hadits adalah ucapan Rasulullah SAW "Penjamin itu adalah orang yang menanggung" (HR Abu Dawud dan Turmudzi, riwayat keduanya dengan kedudukan Hasan, dan riwayat dari Ibnu 
Hibban dengan kedudukan Shahih)

g) Menimbang bahwa nash Syari'ah dan ijtihad para ulama tersebut telah dijadikan dasar oleh Dewan Syariah Nasional (DSN) melalui fatwanya nomor fatwa DSNMUI nomor 11/DSNMUI/IV/2000 tentang Kafalah dan bahkan telah dikodifikasikan oleh Mahkamah Agung RI melalui peraturan Mahkamah Agung nomor 2 tahun 2008 tentang Kompilasi Hukum Ekonomi Syariah yang pada pasal 317 ayat (1) yang setara tegas menyatakan : "penjamin wajib bertanggungjawab untuk membayar utang peminjam jika peminjam tidak melunasi utangnya".

h) Menimbang berdasarkan uraian dalam pertimbangan hukum tersebut diatas maka gugatan pokok Penggugat dengan petitum untuk membatalkan : Surat Kuasa Membebankan Hak Tanggungan nomor 275 tanggal 27 Oktober 2015, Akta Pemberian Hak Tanggungan nomor 241/2015 tanggal 17 Nopember 2015, Sertipikat Hak Tanggungan nomor $5555 / 2015$ harus dinyatakan ditolak.

i) Menimbang bahwa gugatan pokok para Penggugat dinyatakan ditolak maka untuk menjamin kepastian hukum, maka Majelis Hakim harus menyatakan bahwa isi maupun sifat dari Kuasa Membebankan Hak Tanggungan nomor 275 tanggal 27 Oktober 2015, Akta Pemberian Hak Tanggungan nomor 241/2015 tanggal 17 Nopember 2015, Sertipikat Hak Tanggungan nomor $5555 / 2015$ tetap sah dan memiliki kekuatan hukum mengikat.

\section{Analisis Data}

\section{Analisis Prosedur Penyelesaian Sengketa Ekonomi Syariah Di Pengadilan Agama Malang}

Prosedur Penyelesaian Sengketa Ekonomi Syariah melalui Litigasi di Pengadilan Agama Malang sudah diatur dalam Hukum Acara Perdata di lingkungan Peradilan Agama berdasarkan Undang - Undang nomor 4 tahun 2004 tentang Kekuasaan Kehakiman dan diubah menjadi Undang - Undang nomor 48 tahun 2009 dan Undang - Undang nomor 5 tahun 2005 tentang Perubahan Atas Undang Undang nomor 14 tahun 1985 tentang Mahkamah Agung.

Selain diatur dalam Hukum Acara Perdata diatas, prosedur Penyelesaian Sengketa Ekonomi Syariah di Pengadilan Agama Malang juga mengacu pada peraturan perundang undangan yang berlaku khusus yaitu;

a) Het Herziene Inlandsche Reglement (HIR) atau disebut juga Reglement Indonesia yang diperbarui (RIB) yaitu hukum acara perdata yang berlaku di Pulau Jawa dan Madura.

b) Burgelijk Wetboek (BW) meskipun BW sebagai kitab kodifikasi hukum perdata materiil, namun juga memuat hukum acara perdata terutama dalam buku IV tentang Pembuktian dan Kadaluarsa.

c) Undang - Undang nomor 21 tahun 2008 tentang Perbankan Syariah.

Disamping Undang - Undang dan 
peraturan yang disebutkan diatas ada pedoman beracara dalam menyelesaikan Sengketa Ekonomi Syariah antara lain :

a) Peraturan Mahkamah Agung RI nomor 14 tahun 2016 tentang Tata Cara Penyelesaian Sengketa Ekonomi Syariah.

b) Peraturan Mahkamah Agung RI nomor 2 tahun 2008 tentang Kompilasi Hukum Ekonomi Syariah.

c) Peraturan Mahkamah Agung RI nomor 1 tahun 2016 tentang Mediasi.

Berperkara Sengketa Ekonomi Syariah di Pengadilan Agama Malang prosedur atau tata caranya sudah diatur sebagaimana Undang - Undang mengaturnya. Para pihak yang berperkara bisa ajukan gugatan biasa atau gugatan sederhana, dimulai dari pendaftaran perkara, biaya berperkara, sampai proses persidangan. Proses litigasi juga bisa pakai e-Court dimana layanan e-Court ini mempermudah bagi yang ingin mendaftarkan perkaranya secara online, hemat waktu dan hemat biaya baik saat pendaftaran sampai proses persidangan.

\section{Analisis Dasar Hukum Pertimbangan Hakim Dalam Memutus Perkara Nomor 0689/Pdt.G/2017/PA.Mlg Tentang Hak Tanggungan}

Dasar hukum yang ada pada pasal 13 Peraturan Menteri Keuangan Republik Indonesia nomor 106/PMK.06/2013 tentang Perubahan Atas Peraturan Lelang sebagai dalil majelis Hakim tidak menerima Provisi para Penggugat dengan alasan bahwa permohonan Provisi tersebut terlalu prematur. Menurut penulis dasar yang dipakai majelis Hakim tersebut seharusnya sudah tidak bisa dipakai sebagai dasar hukum karena Peraturan Menteri Keuangan nomor 106/PMK.06/2013 tersebut sudah dicabut dan sudah tergantikan dengan Peraturan Menteri Keuangan Nomor 27/PMK.06/2016, pada ketentuan penutupnya dengan jelas disebutkan dalam pasal 99 yang berbunyi "Pada saat Peraturan Menteri ini mulai berlaku, Peraturan Menteri Keuangan Nomor 93/PMK.06/2010 tentang Petunjuk Pelaksanaan Lelang sebagaimana telah diubah dengan Peraturan Menteri Keuangan Nomor 106/PMK.06/2013, dicabut dan dinyatakan tidak berlaku".

Dalam hal ini hakim tidak cermat dan tidak teliti dalam menggunakan pertimbangan hukum, seharusnya hakim memperhatikan asas kepastian hukum agar setiap keputusan yang dikeluarkan menjadi ideal dan tidak menimbulkan masalah baru dikemudian hari. Apalagi ada asas hukum Lex posterior derogat legi priori (hukum yang terbaru mengesampingkan hukum yang lama). Begitu pula ada istilah dalam hukum Islam :

رفع الحكم الثرعي بد ليل شرعي متاخر

"Membatalkan suatu hukum dengan dalil yang datang kemudian."

Teori usul fikih yang menyatakan "pada asasnya semua jenis muamalat dan perjanjian / perikatan adalah saling ridho / rela dan tidak sah muamalat serta tidak sah pula suatu perjanjian / perikatan tanpa adanya kerelaan sejak awalnya. Kerelaan dalam muamalat dan perjanjian / perikatan itu hanya mungkin ada / harus sudah ada pada permulaan (proses)". Imam Ibnu Taimiyah berpendapat "bahwa asal dari semua yang terlihat dan berwujud di alam dunia dengan segala fariasi dan sifatnya adalah mubah (dibolehkan) dan halal bagi manusia sepanjang tidak dinyatakan oleh syariat tentang keharaman dan / atau kenajisannya untuk dimakan, dipakai dan diperjanjikannya, asas yang demikian itu sangat banyak manfaatnya sangatluas 
keberkahannya" sebagai dasar hukum majelis Hakim dalam menjawab dalil gugatan para Tergugat yang menyatakan bahwa pembebanan Hak Tanggungan dalam perkara tersebut menggunakan KUHPerdata dan UU nomor 4 tahun 1996 tentang Hak Tanggungan sebagai tindakan yang bertentangan dengan Syariat Islam.

Dalam penggunaan dalil yang dikemukan majelis Hakim tersebut penulis sependapat dengan majelis Hakim bahwa antara hukum KUHPerdata dan hukum Syariat Islam tidak bertentangan satu dengan yang lainnya, mengingat dalam kaidah muamalah disebutkan:

$$
\text { الاليل على في تحريمها الابا حة حتى يدل }
$$

"Hukum asal dalam semua bentuk muamalah adalah boleh dilakukan kecuali ada dalil yang mengharamkannya". Maksud dari kaidah ini adalah bahwa dalam setiap muamalah dan transaksi pada dasarnya boleh, seperti jual beli, sewa menyewa, gadai, kerjasama (mudharabah atau musyarakah), perwakilan dan lain - lain kecuali yang tegas - tegas diharamkan yang mengakibatkan kemudharatan, tipuan, judi dan riba.

Pembebanan Hak Tanggungan yang dalam khazanah Hukum Islam disebut Kafalah merupakan praktek muamalah yang dibolehkan dalam Syariat Islam, dan majelis Hakim mengutip Fatwa DSN-MUI nomor 11/DSNMUI/IV/2000 untuk menjelaskan pada para Tergugat bahwasanya Hak Tanggungan tidak saja diatur dalam KUHPerdata dan UU nomor 4 tahun 1996 tentang Hak Tanggungan, namun dalam hukum Islam juga diatur dengan istilah Kafalah sebagaimana yang tertuang dalam fatwa DSN-MUI tersebut. Dalam hal ini penulis sependapat sebagian atas apa yang menjadi dasar pertimbangan majelis Hakim tersebut.

Penulis sependapat dalam penggunaan dasar / dalil Fatwa nomor 11/DSN-MUI/IV/2000 tentang Kafalah bagian menimbang, mengingat dan menetapkan pada bagian kesatu dan kedua. Namun untuk bagian ketiga penulis kurang sependapat, karena penyelesaian Sengketa Ekonomi Syariah dalam Akad Kafalah penyelesaiannya melalui Badan Arbitrasi Syariah dan bukan langsung ke Pengadilan Agama, sebagaimana dalam penetapan Fatwa DSN-MUI nomor 11/DSNMUI/IV/2000 tentang Kafalah tersebut berbunyi: "Jika salah satu pihak tidak menunaikan kewajibannya atau jika terjadi perselisihan di antara para pihak, maka penyelesaiannya dilakukan melalui Badan Arbitrasi Syari'ah setelah tidak tercapai kesepakatan melalui musyawarah".

Pertimbangan hukum yang digunakan majelis Hakim dalam memutus perkara gugatan para Tergugat sehingga menyatakan menolak untuk membatalkan permohonan yang termuat dalam pokok perkaranya yaitu pembatalan SKMHT nomor 275 tanggal 27 Oktober 2015, pembatalan APHT nomor 241/2015 tanggal 17 Nopember 2015 dan pembatalan Sertipikat Hak Tanggungan nomor 5555/2015 menggunakan dasar hukum Kompilasi Hukum Ekonomi Syariah (KHES) sebagaimana pasal 361 ayat (1) yang berbunyi "Penjamin wajib bertanggung jawab untuk membayar utang peminjam apabila peminjam tidak melunasi utangnya". Adalah sudah betul dan sesuai perundang - undangan yang berlaku demi mewujudkan kepastian hukum dalam Sengketa Ekonomi Syariah. 


\section{KESIMPULAN}

Berdasarkan analisa yang telah penulis uraikan di atas, maka penulis dapat menyimpulkan sebagai berikut:

1. Penyelesaian Sengketa Ekonomi Syariah di Pengadilan Agama Malang sudah sesuai prosedur berdasarkan UU nomor 3 tahun 2006 Tentang Peradilan Agama. UU nomor 48 tahun 2009 tentang Kekuasaan Kehakiman. UU nomor 5 tahun 2005 tentang Perubahan Atas UU nomor 14 tahun 1985 tentang Mahkamah Agung. Het Herziene Inlandsche Reglement (HIR) atau disebut juga Reglement Indonesia yang diperbarui (RIB), Rechtsreglement voor de Buitengewesten (RBG), Burgelijk Wetboek (BW), UU nomor 21 tahun 2008 tentang Perbankan Syariah, PERMA RI nomor 14 tahun 2016 tentang Tata Cara Penyelesaian Sengketa Ekonomi Syariah. PERMA RI nomor 5 tahun 2016 tentang Sertifikasi Hakim Ekonomi Syariah. PERMA RI nomor 2 tahun 2008 tentang KHES. PERMA RI nomor 1 tahun 2016 tentang Mediasi.

2. Pertimbangan hukum yang digunakan Majelis Hakim pada Putusan Pengadilan Agama Malang nomor $\quad$ 0689/Pdt.G/2017/PA.Mlg sudahlah tepat. Pertimbangan hukum ini menggunakan peraturan perundang - undangan yang berlaku, baik KUHPerdata, UU nomor 4 tahun 1996 tentang Hak Tanggungan Atas Tanah Berseta Benda - benda Yang Berkaitan Dengan Tanah, UU nomor 21 tahun 2008 tentang Perbankan Syariah, Fatwa DSNMUI nomor 11/DSN-MUI/IV/2000 tentang Kafalah, kaidah usul fikih dan PERMA RI nomor 2 tahun 2008 tentang KHES. Namun dalam menggunakan pertimbangan hukum PERMENKEU nomor 106/PMK.06/2013 penulis kurang sependapat karena PERMENKEU tersebut sudah dicabut dan dinyatakan sudah tidak berlaku karena sudah ada PERMENKEU nomor 27/PMK.06/2016.

\section{DAFTAR PUSTAKA}

Fitriani, Latifa, Ifa. 2017. “Jaminan Dan Agunan Dalam Pembiayaan Bank Syariah Dan Kredit Bank Konvensional”. Jurnal Hukum dan Pembangunan 47 No. 1

El Rahman, Izzat, Alfian. 2019. “Eksekusi Hak Tanggungan Dalam Prinsip Ekonomi Syariah”. Jurnal Ekonomi Syariah Lan Tabur. Vol 1 No.1

Zulhefni, Muhammad. 2017. "Kendala Penyelesaian Sengketa Perbankan Syariah Melalui Pengadilan Agama Kota Malang”. Jurisdictie: Jurnal Hukum dan Syariah Vol. 8 No.2

Yasminingtyas, Izana. 2017. Akad At Taba'i (accesoir) Pemberian Hak Tanggungan Dalam Sistem Hukum Perbankan Syariah. Yogyakarta: Tesis UII.

Hidayati, Nurul. 2017. Implementasi Hak Tanggungan Pada Perbankan Syariah, Yogyakarta: Tesis UIN Sunan Kalijaga.

Kementerian Agama Republik Indonesia, Al-Qur'an Terjemah Tafsir Per Kata. 2011. Bandung: Insan Kamil

Subekti. Tjitrosudibio. 2006. Kitab Undang - Undang Hukum Perdata Burgerlijk Wetboek. Jakarta: Pradnya Paramita.

Marwan. Jimmy. 2009. Kamus Hukum. Surabaya: Reality Publisher.

Sutedi, Adrian. 2012. Hukum Hak Tanggungan. Jakarta: Sinar Grafika. 
Arikunto, Suharsimi. 2014. Prosedur Penelitian Suatu Pendekatan Praktik. Jakarta: Rineka Cipta.

Amiruddin. Asikin, Zainal. 2014. Pengantar Metode Penelitian Hukum. Jakarta: Rajawali Pers.

Manan, Abdul. 2016. Hukum Ekonomi Syariah Dalam Perspektif Kewenangan Peradilan Agama. Jakarta: Kencana.

Suadi, Amran. 2017. Penyelesaian Sengketa Ekonomi Syariah Teori Dan Praktik. Depok: Kencana.

Djazuli. 2017. Kaidah - Kaidah Fikih, Kaidah - Kaidah Hukum Islam Dalam Menyelesaikan Masalah - Masalah Yang Praktis. Jakarta: Kencana.

Hadi, Abdul. 2018. Hukum Perbankan Syariah Akad - Akad Dan Dasar Hukumnya. Malang: Setara Press.

Suadi, Amran. 2018. Penyelesaian Sengketa Ekonomi Syariah Penemuan Dan Kaidah Hukum. Jakarta: Prenadamedia Group.

Suadi, Amran. 2019. Eksekusi Jaminan Dalam Penyelesaian Sengketa Ekonomi Syariah. Jakarta: Prenadamedia Group.

Kitab Undang - Undang Hukum Acara Pidana.

UU nomor 35 tahun 1999 perubahan UU 14 tahun 1970, Tentang Ketentuan Pokok Kekuasaan Kehakiman.

UU nomor 4 tahun 1996 Tentang Hak Tanggungan atas tanah beserta benda-benda yang berkaitan dengan tanah.

UU nomor 50 tahun 2009 tentang Peradilan Agama.

Fatwa Dewan Syariah Nasional nomor 11/DSN-MUI/IV/2000 tentang Kafalah.

PERMA RI nomor 2 tahun 2008 tentang Kompilasi Hukum Ekonomi Syariah.

PERMENKEU nomor 27/PMK.06/2016 tentang Petunjuk Pelaksanaan Lelang

Anshori, Nidzom. Wawancara, Malang: 12 Maret 2020

Hadi, Luqman. Wawancara, Malang: 12 Maret 2020

https://www.pa-malangkota.go.id. (5 Juni 2020)

https://www.gurupendidikan.co.id. (5 Juni 2020) 